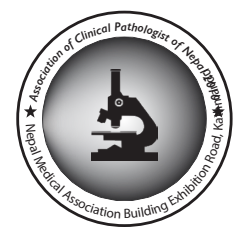

\title{
Evaluation of intrathoracic lesions by image guided fine needle aspiration cytology
}

\author{
Manisha Shrestha ${ }^{1}$, Shovana Karki ${ }^{2}$, Gita Sayami \\ ${ }^{1}$ Department of Pathology, Universal College of Medical Sciences, Bhairahawa, Nepal. \\ ${ }^{2}$ Department of Pathology, Institute of Medicine, Tribhuwan University Teaching Hospital, Kathmandu, Nepal.
}

\section{Keywords: \\ Image guided fine needle aspiration cytology; Intrathoracic lesions; Intrathoracic FNAC; Lung; \\ Pleura;}

\begin{abstract}
Background: Fine needle aspiration cytology has become an indispensable tool for diagnosis of intrathoracic lesions. The purpose of this study was to evaluate the spectrum of intrathoracic lesions by image guided fine needle aspiration cytology.

Materials and Methods: This was a prospective study of 100 patients, who underwent image guided fine needle aspiration cytology of intrathoracic lesions from December 2015 to November 2016 in the Department of Pathology, Institute of Medicine, Tribhuwan University Teaching Hospital.

Results: Of the 100 cases, diagnostic material was obtained in 86 cases, which included 69 cases $(80.23 \%)$ from lung, 7 cases $(8.13 \%)$ from pleura and 10 cases $(11.62 \%)$ from mediastinum. Lung lesions constituted of 61 neoplastic lesions ( $88.40 \%), 3$ cases (4.34\%) suspicious of malignancy, 3 cases (4.34\%) negative for malignancy and 2 non- neoplastic lesions (2.89\%). Squamous cell carcinoma was the most common lesion of the lung. Pleural lesions consisted of 5 neoplastic cases (71.42\%), 1 non- neoplastic case $(14.28 \%)$ and 1 negative for malignancy (14.28\%). Mediastinal lesions consisted of 7 neoplastic lesions (70.00\%) and 3 non- neoplastic lesions (30.00\%). Biopsy for histopathological examination was available in 30 cases. The concordance of diagnosis of lung lesions by fine needle aspiration cytology and histopathology was $90.90 \%$. Image guided FNAC had sensitivity of $95.83 \%$ and specificity of $50.33 \%$ in diagnosing intrathoracic lesions. The positive predictive value of image guided FNAC in diagnosis of intrathoracic lesions was $92.00 \%$ and negative predictive value of 66.67 percent.
\end{abstract}

Conclusion: Image guided fine needle aspiration cytology of intrathoracic lesions permits categorization and distinction between non- neoplastic and neoplastic lesions.

\section{Correspondence:}

Dr. Manisha Shrestha, MD

Department of Pathology, Universal College of Medical Sciences,

Bhairahawa, Nepal.

ORCID ID: 0000-0003-2313-6835

Email: mansha.stha@gmail.com

Reveived : August $13^{\text {th }} 2018$; Accepted : January $14^{\text {th }} 2019 ;$ Published : March $29^{\text {th }} 2019$

Citation: Shrestha M, Karki S, Sayami G. Evaluation of intrathoracic lesions by image guided fine needle aspiration cytology. J Pathol Nep 2019;9:1464-8. DOI 10.3126/jpn.v9i1.23363

Copyright: This is an open-access article distributed under the terms of the Creative Common Attribution 4.0 International License, which permits unrestricted use, distribution, and reproduction in any medium, provided the original author and source are credited.

\section{INTRODUCTION}

Thoracic cavity is the second largest hollow space of the body and site of various non- neoplastic and neoplastic pathologies. Different radiological modalities have enabled the detection of these lesions, but may fail to distinguish between benign and malignant cases. ${ }^{1}$ A confirmed pathologic diagnosis is therefore essential for patient management. ${ }^{2}$ However, blind aspiration has the inherent drawback of poor lesion localization and lower diagnostic accuracy. This has been overcome with the advent of ultrasonography (USG) and computed tomography (CT) guided fine needle aspiration cytology (FNAC) which has a high sensitivity and specificity in diagnosing deep seated 
Table 1: Age wise distribution of various intrathoracic sites of FNAC $(n=86)$

\begin{tabular}{|c|c|c|c|c|c|c|c|c|c|}
\hline \multirow[b]{2}{*}{ Site of FNAC } & \multirow[b]{2}{*}{ 11- 20} & \multicolumn{7}{|c|}{ Age range years } & \multirow[t]{2}{*}{ Tota } \\
\hline & & 21- 30 & 31- 40 & $41-50$ & $51-60$ & $61-70$ & $71-80$ & 81- 90 & \\
\hline Lung & 0 & 1 & 0 & 4 & 18 & 26 & 18 & 2 & 69 \\
\hline Mediastinum & 1 & 2 & 1 & 2 & 2 & 1 & 1 & 0 & 10 \\
\hline Pleura & 3 & 0 & 0 & 0 & 0 & 2 & 2 & 0 & 7 \\
\hline Total & 4 & 3 & 1 & 6 & 20 & 29 & 21 & 2 & 86 \\
\hline
\end{tabular}

Table 2: Gender distribution of various intrathoracic sites of FNAC $(n=86)$

\begin{tabular}{lcc}
\hline Site of FNAC & Male & Female \\
\hline Lung & $39(56.52 \%)$ & $30(43.47 \%)$ \\
Mediastinum & $4(40.00 \%)$ & $6(60.00 \%)$ \\
Pleura & $5(71.42 \%)$ & $2(28.57 \%)$ \\
\hline Total & $\mathbf{4 8}$ & $\mathbf{3 8}$ \\
\hline
\end{tabular}

lesions of the thorax by simple outpatient procedure with a low cost to the patient as compared to higher cost, morbidity and lengthy hospital stay in surgical biopsies. ${ }^{3}$

In Nepal, lung cancer is the most common malignancy in males and the third most common among females. ${ }^{4-5}$ Mediastinal lesions can be difficult to biopsy and so FNAC plays a pivotal role. The commonly encountered lesions in the anterior mediastinum are thymic lesions, lymphoma and germ cell tumors. The common lesions of the middle mediastinum are bronchogenic cysts and vascular lesions whereas the common lesions of the posterior mediastinum are neurogenic tumors. ${ }^{6}$ Pleural lesions can be primary or metastatic. Common primary lesions include mesothelioma and solitary fibrous tumor. ${ }^{7}$ This study has been conducted to evaluate the spectrum of intrathoracic lesions by image guided FNAC.

\section{MATERIALS AND METHODS}

This was a cross sectional, observational hospital based study which included 100 patients, who underwent image guided FNAC of intrathoracic lesions from December 2015 to November 2016 in the Department of Pathology, Institute of Medicine, Tribhuwan University Teaching Hospital. After obtaining consent, detailed clinical and radiological information was collected and the patient was subjected to FNAC under image guidance. The FNAC was performed by a radiologist or in conjunction with a pathologist using 23-gauge needle attached to a $10 \mathrm{ml}$ disposable syringe. Aspirates were smeared on clean glass slides, wet fixed or air dried and stained by papanicolaou and May-GrunwaldGiemsa (MGG) stains. The surgical specimens were fixed in $10 \%$ formalin, then routinely processed and stained by Haematoxylin and Eosin (HE) stain.

\section{RESULTS}

Table 3: FNAC diagnosis of lung lesions $(n=69 / 86)$

\begin{tabular}{lcc}
\hline FNAC diagnosis & Frequency & $\begin{array}{c}\text { Percentage } \\
(\mathbf{\%})\end{array}$ \\
\hline $\begin{array}{l}\text { Squamous cell carcinoma } \\
\text { (fig1A and B) }\end{array}$ & 27 & 39.13 \\
\hline $\begin{array}{l}\text { Adenocarcinoma } \\
\text { Small cell carcinoma (fig.2 } \\
\text { and 3) }\end{array}$ & 19 & 27.53 \\
Non-small cell carcinoma & 6 & 8.69 \\
Suspicious of malignancy & 3 & 8.69 \\
Negative for malignancy & 3 & 4.34 \\
Adenosquamous carcinoma & 2 & 4.34 \\
Malignant lesion & 1 & 2.89 \\
Inflammatory lesion & 1 & 1.44 \\
\hline Tuberculosis & 1 & 1.44 \\
\hline Total & $\mathbf{6 9}$ & 1.44 \\
\hline
\end{tabular}

Of the 2593 FNACs reported in the department of pathology from December 2015 to November 2016, intrathoracic image guided FNAC constituted of 100 cases. Fourteen cases were excluded from the study as smears were composed of mainly hemorrhage. Among the 86 cases included in the study, biopsy for histopathological examination was available in 30 cases.

The age of the patients for intrathoracic FNAC ranged from 14 years to 83 years with a mean age of 60 years and median age of 63 years. Age wise distribution of the patients according to the site is given in table 1 .

Males constituted 48 cases (55.81\%) and females constituted 38 cases $(44.18 \%)$ of intrathoracic FNAC. Gender wise distribution of patients according to site is given in table 2 .

The FNAC of lung lesions consisted of 61 neoplastic lesions $(88.40 \%), 3$ cases $(4.34 \%)$ of suspicious of malignancy, $3(4.34 \%)$ negative for malignancy and 2 non neoplastic lesions $(2.89 \%)$. Squamous cell carcinoma was the most common diagnosis and consisted of 27 cases (39.13\%). Table 3 shows the FNAC diagnosis of lung lesions.

The FNA of pleural lesions consisted of 5 neoplastic cases (71.42\%), 1 non neoplastic case $(14.28 \%)$ and 1 negative for malignancy $(14.28 \%)$. The most common lesion in the pleura was metastatic small cell carcinoma which 
Table 4: Comparison of FNAC and histopathological diagnosis of lung lesions

\begin{tabular}{|c|c|c|c|c|c|c|}
\hline \multirow[b]{2}{*}{ HISTOPATHOLOGICAL DIAGNOSIS } & \multicolumn{6}{|c|}{ FNAC DIAGNOSIS } \\
\hline & $\begin{array}{c}\mathrm{SqCC} * \\
(\mathrm{n}=8)\end{array}$ & $\begin{array}{l}\text { Adenoca*** } \\
\quad(n=4)\end{array}$ & $\begin{array}{l}\mathrm{SCC}^{\dagger} \\
(\mathrm{n}=5)\end{array}$ & $\begin{array}{c}\text { NSCC } \S \\
(n=4)\end{array}$ & $\begin{array}{c}\text { Suspicious of } \\
\text { malignancy } \\
(n=2)\end{array}$ & $\begin{array}{c}\text { Negative for } \\
\text { malignancy } \\
(\mathrm{n}=1)\end{array}$ \\
\hline Squamous cell carcinoma & 7 & 0 & 1 & 2 & 1 & 0 \\
\hline Adenocarcinoma & 0 & 3 & 0 & 0 & 1 & 1 \\
\hline Small cell carcinoma & 0 & 0 & 4 & 0 & 0 & 0 \\
\hline Non-small cell carcinoma & 0 & 0 & 0 & 1 & 0 & 0 \\
\hline Poorly differentiated carcinoma & 0 & 0 & 0 & 1 & 0 & 0 \\
\hline Inadequate for opinion & 1 & 1 & 0 & 0 & 0 & 0 \\
\hline
\end{tabular}

*squamous cell carcinoma; **adenocarcinoma; †small cell carcinoma; \$nonsmall cell carcinoma

constituted 2 cases $(28.56 \%)$. There was one case $(14.28 \%)$ each of Adenomatoid tumor, Spindle cell carcinoma, Malignant mesothelioma and Tuberculosis.

All the mediastinal lesions in the study were from the anterior mediastinum, out of which 7 cases were from mediastinal mass and remaining 3 cases from mediastinal lymph node. The mediastinal mass consisted of 3 cases $(30.00 \%)$ of thymoma and 1 case $(10.00 \%)$ respectively each of squamous cell carcinoma, small cell carcinoma, metastatic germ cell tumor and thymic carcinoma. The mediastinal lymph nodes consisted of 2 cases $(20.00 \%$ respectively) of Tuberculosis and 1 case (10.00\%) of reactive lymphadenopathy.

Out of the total 69 cases of FNAC of lung lesions, core needle biopsy was available in 24 cases. There was concordance of $90.90 \%$ in the diagnosis of lung lesions by FNAC and histopathology. Table 4 shows the comparison of FNAC and histopathological diagnosis of lung lesions.

Out of the total 7 cases of FNAC from pleural lesions,
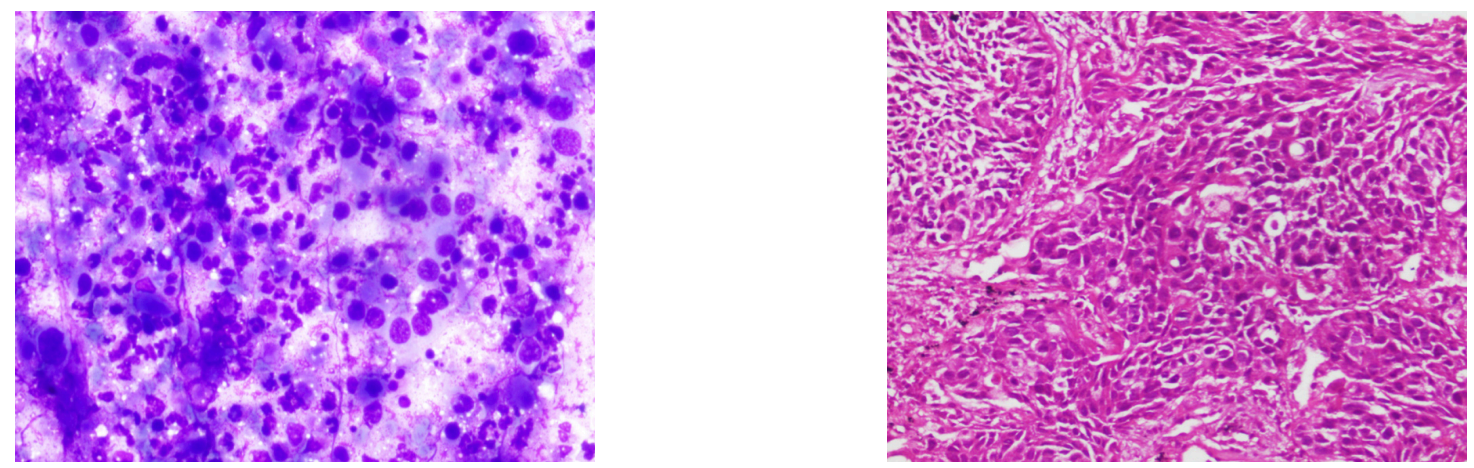

Figure 1: A) FNAC smear with squamous cell carcinoma showing singly scattered tumor cells and anucleated squames (MGG stain, X400). B) Biopsy of squamous cell carcinoma (HE stain, X200)

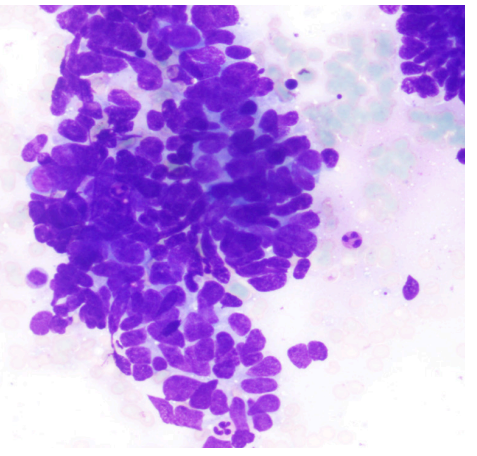

Figure 2: Small cell carcinoma with tumor cells showing nuclear molding (MGG stain, X400)

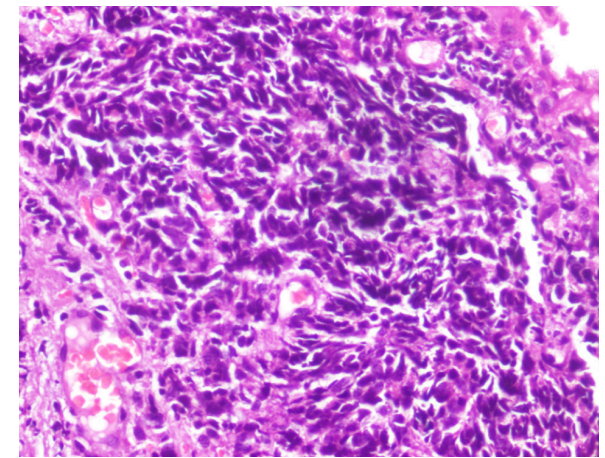

Figure 3: Biopsy of small cell carcinoma (HE stain, X400) 

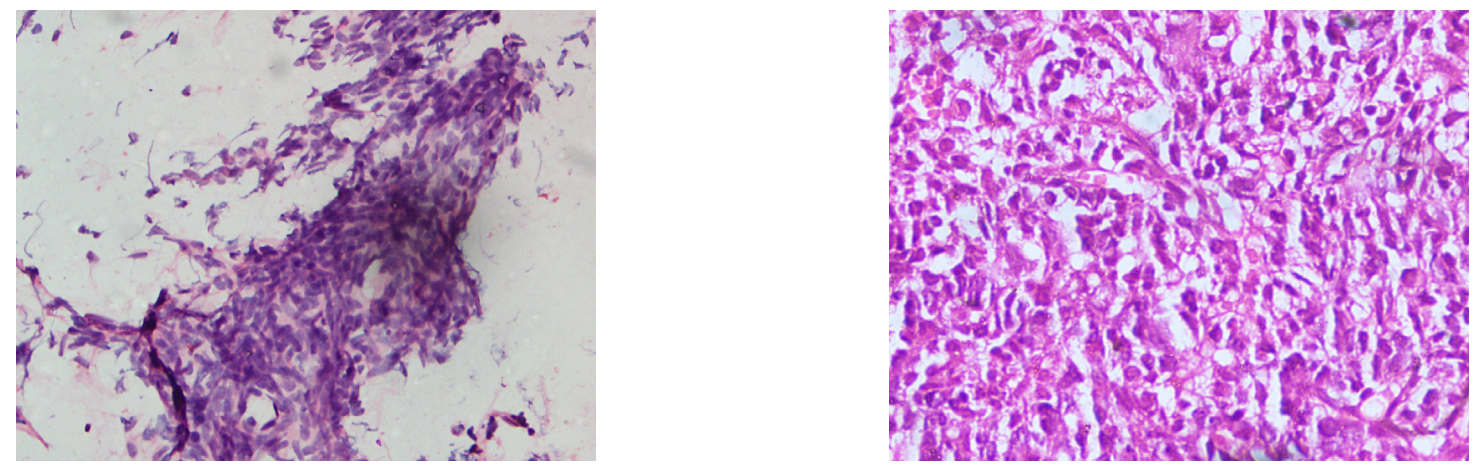

Photograph 4: A) FNAC smears showing spindle cell neoplasm (MGG stain, X200). On biopsy the lesion was solitary fibrous tumor (B)

biopsy was available in 4 cases. Three cases of which had same diagnosis on histopathological examination. The case of spindle cell neoplasm (fig.4A) on histopathological examination was solitary fibrous tumor (fig.4B). The only discordant case was of adenomatoid tumor, which was diagnosed as Tuberculosis on biopsy. On retrospective evaluation, mesothelial cells were mistaken for adenomatoid tumor and the tubercular component must have been missed during aspiration.

Out of the total 10 cases from the mediastinum, biopsy was available in 2 cases. One case was of small cell carcinoma which was proven as the same on biopsy and the other case of reactive lymph node on FNAC was necrotizing granulomatous inflammation on biopsy.

Image guided FNAC was found to have sensitivity of $95.83 \%$ and specificity of $50.33 \%$ in diagnosing intrathoracic lesions. The positive predictive value of image guided FNAC in diagnosis of intrathoracic lesions was $92.00 \%$ and negative predictive value of 66.67 percent.

\section{DISCUSSION}

The patient demographics in this study was similar to those of other reported studies with a wide age range from 14- 83 years and the male to female ratio of 1.2:1. In the study by Knudsen et al8, age range was from 17- 84 years with a male: female ratio of 1.72:1.

In the present study, out of the total 86 cases, 69 cases $(80.23 \%)$ were from the lung, 7 cases $(8.13 \%)$ from the pleura and 10 cases $(11.62 \%)$ from the mediastinum. In a study by Gouliamos et al 9 with total of 64 cases, 50 cases (78.12\%) were from the lung and 14 cases $(21.87 \%)$ were from the pleura, and no cases from the mediastinum.

The predominance of neoplastic lesions in the lung, is similar to the findings of Kalhan et $\mathrm{al}^{10}$ and Konjengbam et $\mathrm{al}^{11}$. Our study showed squamous cell carcinoma to be the most common lesion in the lung, which is similar to the findings of Konjengbam et $\mathrm{al}^{11}$, whereas Kalhan et $\mathrm{al}^{10}$ found adenocarcinoma to be the most common lesion.

In comparing the pleural lesions, both our study and Gouliamos et $\mathrm{al}^{9}$ had a predominance of neoplastic lesion. Small cell carcinoma was the most common lesion in our study. In contrast, Gouliamos et $\mathrm{al}^{9}$ observed a predominance of benign cases.

All the mediastinal lesions in our study showed anterior mediastinal presentation. Adler et $\mathrm{al}^{12}$ and Karki et a ${ }^{13}$ observed a predominance of anterior mediastinal lesions. Thymic lesions were the most common findings in our study, with 3 cases $(30.00 \%)$ of thymoma and 1 case $(10.00 \%)$ of thymic carcinoma. Karki et a ${ }^{13}$ had a similar finding of preponderance of thymoma, whereas Adler et al ${ }^{12}$ had a predominance of metastatic carcinoma.

Comparison of validity parameters were done with a similar study done by Sarker et $\mathrm{al}^{14}$. Both the studies showed a similar sensitivity of image guided FNAC in diagnosis of intrathoracic lesions with Sarker et $\mathrm{al}^{14}$ having a sensitivity of $93.85 \%$ and the present study having a sensitivity of $95.83 \%$. However, the specificity in the two studies were contrasting with Sarker et $\mathrm{al}^{14}$ showing a specificity of $100 \%$, whereas the present study has a specificity of $50.00 \%$. The positive predictive value of Sarker et al ${ }^{14}$ was $100 \%$, whereas the present study has $92.00 \%$ positive predictive value. The negative predictive value of Sarker et $\mathrm{al}^{14}$ was $89.74 \%$ and the present study has a value of $66.67 \%$. The reason for the lower specificity of FNAC in the present study is due to the low value of true negative cases. In the cases where the cytological diagnosis was negative for malignancy, a subsequent biopsy was either not done or the biopsy was referred to other centers. This, thereby reduced the number of true negative cases in the present study. However, sensitivity of the present study was similar to that of Sarker et $\mathrm{al}^{14}$ as true negative cases have no effect on the determination of sensitivity.

\section{CONCLUSION}

Image guided FNAC upholds an unquestionable value as 
a mandatory diagnostic procedure in the assessment of neoplastic and non- neoplastic intrathoracic lesions.

\section{Conflict of interest: None}

\section{REFERENCES}

1. Boiselle PM, Patz EF, Vining DJ, Weissleder R, Shepers JA, Mclound TC. Imaging of mediastinal lymph nodes : CT, MRI and FDGPET. Radiographics 1998;1061-9. Crossref

2. Adhikari RC, Tuladhar A, Shrestha S, Sharma SK. Deepseated thoracic and abdominal lesions: usefulness of ultrasound guided fine needle aspiration cytology, a 3 year experience. Nepal Med Coll J 2010;12:20-5. Crossref

3. Parajuli S, Tuladhar A, Basnet RB. Ultrasound and computed tomography guided fine needle aspiration cytology in diagnosing intra-abdominal and intra-thoracic lesions. J Pathol Nep 2011;1:17-21. Crossref

4. Pradhananga KK, Baral M, Shrestha BM. Multi-institution Hospital-based Cancer Incidence Data for Nepal - An Initial Report. Asian Pacific Journal of Cancer Prevention 2009;10:259-62. Crossref

5. Pun CB, Pradhananga KK, Siwakoti B, Moore MA. Malignant Neoplasm Burden in Nepal - Data from the Seven Major Cancer Service Hospitals for 2012. Asian Pacific Journal of Cancer Prevention 2015;16:659-63.

6. Weisbrod L, Lyons DJ, Tao LC, Chamberlain DW. Percutaneous Aspiration Biopsy of Mediastinal Lesions. AJR 1984;143:525-29. Crossref

7. Walker CM, Takasugi JE, Chung JH, Reddy GP, Done SL, Pipavath SN, et al. Tumorlike Conditions of the Pleura. Radiographics 2012;32:971-85. Crossref
8. Knudsen DU, Nielsen SM, Hariri J, Christensen J, Kristensen S. Ultrasonographically Guided Fine-Needle Aspiration Biopsy of Intrathoracic Tumors. Acta radiol 1996;37:327-31. Crossref

9. Gouliamos AD, Giannopoulos DH, Panagi GM, Fletoridis NK, Delieorgi-politi HA, Vlahos LJ. Computed tomographyguided fine needle aspiration of peripheral lung opacities:An initial diagnostic procedure. Acta Cytol 2000;44:344-8. Crossref

10. Kalhan S, Sharma P, Sharma S, Dudani S, Ramakrishnan T, Chowdhry A. Evaluation of precision of guidance techniques in image guided fine needle aspiration cytology of thoracic mass lesions. J Cytol 2012;29(1):6-10. $\underline{\text { Crossref }}$

11. Konjengbam R, Singh NB, Gatphoh SG. Computed tomography guided percutaneous transthoracic fi ne needle aspiration cytology of pulmonary mass lesions : Two years cross sectional study of 61 cases. Journal of Medical Society 2014;28:112-6. Crossref

12. Alder OB, Rosenberger A, Peleg H. Fine-Needle Aspiration Biopsy of Mediastinal Masses: Experiences. AJR 1983;140:893-96. $\underline{\text { Crossref }}$

13. Karki S, Chalise S. Spectrum of Intrathoracic Lesions by Guided Fine Needle Aspiration Cytology. Journal of Pathology of Nepal 2004;18:114-7. Crossref

14. Sarker RN, Rabbi AF, Hossain A, Quddus MA, Chowdhury $\mathrm{N}$, Sarker T et al. Computed tomography guided transthoracic fine needle aspiration cytology in the diagnosis of sonographically non-approachable intrathoracic masses: A study of 100 cases. J Dhaka Med Coll 2011;20:25-31. $\underline{\text { Crossref }}$ 